\title{
ON THE NEXUS BETWEEN SERVICES EXPORT AND SERVICE SECTOR GROWTH IN INDIAN CONTEXT
}

\author{
Mousumi Bhattacharya \\ Rajiv Gandhi Indian Institute of Management, \\ Shillong, Meghalaya, India. \\ Mousumi Bhattacharya, \\ Rajiv Gandhi Indian Institute of Management, \\ Nongthymmai. \\ msb@iimshillong.ac.in \\ Sharad Nath Bhattacharya, \\ Rajiv Gandhi Indian Institute of Management, \\ Shillong, Meghalaya, India.
}

\begin{abstract}
The rise of services sector as the most dynamic sector of the Indian Economy has in many ways been a revolution. While the share of services in India's GDP has risen over the post-independence period a marked acceleration was observed during the last decade. The paper attempts to undertake a detailed analysis of the service sector growth and how services export play a crucial role in it. The study aims to investigate the possible cointegration and direction of causality between services export and service sector growth in India for the period 2004-05 to 2012-13. The results reveal that both software and non-software miscellaneous services (business, financial and communication) have led to the services sector growth. Bidirectional causality is observed between software services export and growth of the services sector and between non software services export and growth of the services sector while unidirectional causality is observed from software services export to nonsoftware services export.
\end{abstract}

Keywords services sector growth, service export, software services, cointegration, causality

\section{Introduction}

The services sector in the last few years has emerged as the largest and fastest growing sector of the economy with about 57 percent contribution to the gross domestic product. The sector has been a dominant sector in India's GDP and covers a wide range of activities like sophisticated IT and ITeS to those of carpenters and plumbers. In the Indian context this sector has contributed substantially to foreign direct investment, trade flows, employment, national and state incomes. The 1990s economic reform paved the way for trade liberalization along with major policy changes in the domestic business environment which have helped the emergence of service sector as a key player in India's growth story.

The contribution of services to the country's trade flows have been on an upward trajectory 
since 1990s. In the world services exports, India's share increased from 0.6 percent in 1990 to 1.1 percent in 2000 and further to 3.3 percent in 2013. Since 1996, the growth rate of services exports has been higher than that of the rest of the world. In the recent years the growth of the services sector has been due to the growth of financing, insurance, real estate, and business services. The software exports accounts for about $46 \%$ of India's total services exports and IT and ITeS has become one of the significant growth catalysts for the country's growth. India ranked $10^{\text {th }}$ in terms of overall GDP and $12^{\text {th }}$ in terms of services GDP in 2012 amongst the world's top 15 countries in terms of GDP. India has the second fastest growing services sector with its CAGR at 9 percent, just below China's 10.9 percent during the last 11 year period from 2001 to 2012. (Economic Survey Report 201314). Among the leading exporters of services in the world, India with a CAGR of 20.2 percent had the fastest growth followed by China at 16.6 percent (Table 1).

Table 1: Performance Summary of the Services Sector across Countries

\begin{tabular}{|c|c|c|c|c|c|c|c|}
\hline \multirow{2}{*}{ Country } & \multicolumn{2}{|c|}{ Rank } & \multirow{2}{*}{$\begin{array}{c}\text { CAGR } \\
(2001-12)\end{array}$} & \multicolumn{3}{|c|}{ Share of Services in GDP } & \multirow{2}{*}{$\begin{array}{c}\text { Services Ex- } \\
\text { port Growth } \\
\text { CAGR(2001- } \\
\text { 2013) }\end{array}$} \\
\hline & $\begin{array}{c}\text { Overall } \\
\text { GDP }\end{array}$ & $\begin{array}{c}\text { Services } \\
\text { GDP }\end{array}$ & & 2001 & 2011 & 2012 & \\
\hline US & 1 & 1 & 2.1 & 77.2 & 78.9 & 79.2 & 7.7 \\
\hline China & 2 & 3 & 10.9 & 40.5 & 43.4 & 44.6 & 16.6 \\
\hline Japan & 3 & 2 & 0.6 & 69.9 & 72.7 & 72.3 & 7 \\
\hline Germany & 4 & 4 & 1.2 & 69.0 & 68.5 & 66.6 & 10.8 \\
\hline France & 5 & 5 & 1.4 & 75.0 & 79.2 & 79.2 & 9.4 \\
\hline UK & 6 & 6 & 2.1 & 73.3 & 77.9 & 78.8 & 7.8 \\
\hline Brazil & 7 & 8 & 3.6 & 67.1 & 67.0 & 68.5 & 12.9 \\
\hline Russia & 8 & 10 & 5.4 & 55.7 & 58.9 & 60.1 & 15.9 \\
\hline Italy & 9 & 7 & 0.4 & 69.9 & 73.3 & 73.8 & 5.6 \\
\hline India & 10 & 12 & 9.0 & 51.3 & 55.7 & 56.9 & 20.2 \\
\hline Canada & 11 & 9 & 2.6 & 65.8 & 71.2 & 71.1 & 6.2 \\
\hline Australia & 12 & 11 & 3.2 & 69.6 & 69.4 & 69.5 & 9.4 \\
\hline Spain & 13 & 13 & 2.5 & 64.8 & 70.9 & 71.6 & 8.3 \\
\hline Mexico & 14 & 14 & 3.0 & 63.3 & 60.3 & 60.1 & 4.0 \\
\hline South Korea & 15 & 15 & 3.4 & 58.5 & 57.5 & 57.7 & 11.8 \\
\hline
\end{tabular}

Source: Economic Survey 2013-14, Reserve Bank of India Publication. 
The growth of services-sector GDP has been higher than that of overall GDP during 200001 to 2013-14. Despite deceleration, services GDP growth at 6.8 per cent was above the 4.7 per cent overall GDP growth in 2013-14. During the period 2000-2010, growth rate of Indian economy was about $7.2 \%$ and around $63 \%$ of this growth came from the growth of the services. This has led people to belief that India has inherent strength in services and the rapid service led growth resulted from India's success in exporting skill intensive services. The growth of services export contributed to accelerate growth of the services sector.

\section{Literature Review}

King and Levine (1993) postulated that financial services can affect growth through enhanced capital accumulation and/or technical innovation. The role of financial services in channeling investment funds to their most productive uses, thereby promoting growth of output and incomes was stressed by Goldsmith 1969. According to Francois 1990, the growth of intermediation services contributed to overall economic growth and development because they allow specialization to occur. The importance of services for export performance rises with per capita income as business, distribution, and communications services become the most important sectoral elements of overall exports in terms of interindustry linkages (Francois \& Reinhert 1996). Countries with open financial and telecommunication sector grew on an average 1percentage point faster than other countries. The impact of trade liberalization and the in the 1990s and the development of services sector has further contributed to industrial output and productivity growth (Banga and Golder 2007). In the light of the above context the study aims to find out whether services export especially software services have contributed significantly services sector growth.

\section{Methodology}

Quarterly data of miscellaneous services export (software services export [SOFTWARE] and non-software miscellaneous services [NONSOFTWARE]) are obtained from Reserve Bank of India website and has been used in the study. The non-software miscellaneous services export includes business, financial and communication services. The contribution made by services (including construction, trade, hotels, transport \& communication, financing, insurance, real estate and business services along with community, social and personal services) to the GDP at factor cost at constant prices (base year 2004-05) measures growth of the services sector over the years. The time period of the study is 2004-05 to 2012-13. The objective here is to address the impact of software and nonsoftware miscellaneous services export on growth of the services sector. The study uses a Granger causality test in a multivariate Vector Autoregressive (VAR) framework to examine causality between services sector growth and software and nonsoftware miscellaneous services export. The next few sub-sections introduce the econometric tools necessary to carry out the subsequent analysis cointegration and causality.

Test for stationarity: The stationarity property of the variables are investigated using Augmented Dickey Fuller (ADF) (1979) and PhillipsPerron (PP) (1988) test. 
Cointegration Test: The existence of long term relationship among variables is tested through cointegration test of Johansen (1988) and Johansen and Juselius (1990). On a VAR approach initiated by Johansen (1988) the Cointegration Test of maximum likelihood has been developed. According to Johansen (1988), a p-dimensional VAR model, involving up to k-lags, can be specified as below.

$Z_{t}=\prod_{1} Z_{t-1}+\prod_{2} Z_{t-2}+\ldots \ldots \ldots \ldots \Pi_{k} Z_{t-k}+\varepsilon_{t}$

where $Z_{t}$ is a $(p \times 1)$ vector of $p$ potential endogenous variables and each of the $\Pi_{i}$ is a $(p \times p)$ matrix of parameters and $\varepsilon_{t}$ is the white noise term. Equation (1) can be formulated into an Error Correction Model (ECM) form as below.

$$
\Delta Z_{t}=\prod_{k} Z_{t-k}+\sum_{i=1}^{k-1} \theta_{i} \Delta Z_{t-i}+\varepsilon_{t}
$$

where $\Delta$ is the first difference operator, and $\Pi$ and $\theta$ are $p$ by $p$ matrices of unknown parameters and $k$ is the order of the VAR translated into a lag of $k-1$ in the ECM and $\varepsilon_{t}$ is the white noise term. Evidence of the existence of cointegration is the same as evidence of the rank $(r)$ for the $\Pi$ matrix. Johansen and Juselius (1990) have shown that the rank of $r$ of $\Pi$ in equation (2) is equal to the number of cointegrating vectors in the system. When the rank of $\Pi$ is reduced i.e. [ $1 \leq \operatorname{Rank} \Pi \leq(p-1)]$, in this case, even if all the variables are individually I(1), the levelbased long-run component would be stationary. In this case, there are $(p-1)$ cointegrating vectors.
The appropriate modelling methodology here is the Vector-Error Correction Model (VECM). Johansen and Juselius (1990) have developed two Likelihood Ratio Tests. The first test is the Likelihood Ratio Test based on the maximal Eigen value, which evaluates the null hypothesis of ' $\mathrm{r}$ ' cointegrating vector(s) against the alternative of ' $\mathrm{r}+1$ ' cointegrating vectors. The second test is the Likelihood Ratio Test based on the Trace Test, which evaluates the null hypothesis of, at most, ' $r$ ' cointegrating vector(s) against the alternative hypothesis of more than ' $r$ ' cointegrating vectors. If the two variables are I(1), but cointegrated, the Granger Causality Test will be applied in the framework of ECM.

\section{Vector Error Correction Model (VECM):} When two variables are I(1) and co-integrated than the direction of causal relationship is detected in a VECM (Vector Error Correction Model) framework. In order to capture the impact of variables observed in the past time period in explaining the future performance, the optimal lag length $\mathrm{p}$ is chosen and the criteria used in selecting the VAR model and optimal lag length require the combination of information criterion (minimum of LL or LR or FPE or AIC or SIC or HQIC value). Engel and Granger (1987) have found that, in the presence of co-integration, there always exists a corresponding error-correction representation, captured by the error-correction term (ECT). The ECT captures the long-run adjustment of co-integration variables. In this study VECM is applied and the equations regarding the model 
are presented below:-

$$
\begin{aligned}
& \Delta \operatorname{LnGRWSER}_{t}=\sum_{j=1}^{p-1} \beta_{11, j} \Delta \operatorname{LnGRWSER}_{t-j}+\sum_{j=1}^{p-1} \beta_{12, j} \Delta \operatorname{LnSOFTWARE}_{t-j}+\sum_{j=1}^{p-1} \beta_{13, j} \operatorname{LLnNONSOFTWARE}_{t-j}+\alpha_{1} \text { ECT }_{t-1}+\varepsilon_{1 t} \ldots . .\left(3 a{ }^{\prime}\right. \\
& \triangle \operatorname{LnSOFTWARE}_{t}=\sum_{j=1}^{p-1} \beta_{21, j} \operatorname{LLNSOFTWARE}_{t-j}+\sum_{j=1}^{p-1} \beta_{22, j} \operatorname{LLnGRWSER}_{t-j}+\sum_{j=1}^{p-1} \beta_{23, j} \operatorname{LLNNONSOFTWARE}_{t-j}+\alpha_{2} \text { ECT }_{t-2}+\varepsilon_{2 t} \cdots \\
& \Delta \text { LnNONSOFTWARE } E_{t}=\sum_{j=1}^{p-1} \beta_{31, j} \text { LLNONSOFTWARE } E_{t-j}+\sum_{j=1}^{p-1} \beta_{32, j} \Delta \operatorname{LnGRWSER}_{t-j}+\sum_{j=1}^{p-1} \beta_{33, j} \operatorname{LLnSOFTWARE}_{t-j}+\alpha_{3} \text { ECT }_{t-3}+\varepsilon_{3 t} \ldots(3 c)
\end{aligned}
$$

where $\Delta$ is the first difference operator and $\varepsilon_{1 t}, \varepsilon_{2 t}$ and $\varepsilon_{3 t}$ are white noise. ECT is the error correction term, and $\mathrm{p}$ is the order of the VAR, which is translated to lag of $p-1$ in the ECM. $\alpha_{1}, \alpha_{2}$ and $\alpha_{3}$ represent the speed of adjustment after the GRWSER, SOFTWARE and NONSOFTWARE deviate from the long run equilibrium in period $\mathrm{t}-1$.

Impulse Response Analysis: Impulseresponses are the changes in the future predicted values due to a change in the current period values. Typically in a VAR, the coefficient estimates of the individual equations are of little or no importance. Instead of static interpretation of the effects of changes in any of the variables in the system, Impulse Responses (IR) provide a dynamic response curve that depicts the effects of a change in one of the variables, considering the effects of the other variables in the system. In the present study, the orthogonalized IR analysis is done by changing the order of the equations to see whether any change in the IR function is revealed.

\section{Findings}

Stationarity Test: The null hypothesis of unit root is not rejected for all the level series of the variables. However when ADF and PP tests are applied to the first differences of the series the null hypothesis cannot be accepted indicating that the variables are stationary. So, it can be concluded that all the variables considered for the study are I(1) processes.

\section{Table 2: Test of Unit Root Test Hypothesis}

\begin{tabular}{|l|l|l|l|l|l|}
\hline Series & \multicolumn{2}{l|}{ ADF } & \multicolumn{2}{l|}{ PP } & \multirow{2}{*}{ Remarks } \\
\hline & Level & First Difference & Level & First Difference & \\
\hline LnGRWSER & 1.568010 & $-32.37354 * * *$ & 1.568010 & $-32.37354 * * *$ & $\mathrm{I}(1)$ \\
\hline LnSOFTWARE & -1.29956 & $-5.641286 * * *$ & -1.29956 & $-24.76368 * * *$ & $\mathrm{I}(1)$ \\
\hline LnNONSOFTWARE & -1.28851 & $-5.202963 * * *$ & -1.28851 & $-5.202963 * * *$ & $\mathrm{I}(1)$ \\
\hline
\end{tabular}

(a)The critical values are those of MacKinnon (1991).

(b) $* * *, * *$ and $*$ represent the rejection of null hypothesis at $1 \%, 5 \%$ and $10 \%$ levels of significance respectively.

The variables LnGRWSER, LnSOFTWARE and LnNONSOFTWARE, are I(1) processes according to ADF, PP tests as revealed in Table 2. 
Johansen Cointegration Test: In Table 3 cointegration vectors is equal to 1 for the Trace below Johansen Cointegration Test results for the cointegration rank $\mathrm{r}$ is presented. Table 3 shows that the number of statistically significant statistic and 1 for the Max-Eigen value statistic. The results suggest that there is a long-run relationship among the variables considered for the study.

Table 3: Johansen - Juselius Cointegration Test Results

[No deterministic trend (restricted constant)]

\begin{tabular}{|c|c|c|c|c|}
\hline $\mathrm{H}_{0}$ & $\mathrm{H}_{1}$ & $\lambda_{\text {trace }}$ & $C V_{(\text {trace }, 5 \%)}$ & Prob. ${ }^{* *}$ \\
\hline$r=0$ & $r \geq 1$ & 144.2083 & 35.19275 & $0.0000^{* *}$ \\
\hline$r \leq 1$ & $r \geq 2$ & 18.51399 & 20.26184 & 0.0854 \\
\hline$r \leq 2$ & $r \geq 3$ & 8.500166 & 9.164546 & 0.0667 \\
\hline $\mathrm{H}_{0}$ & $\mathrm{H}_{1}$ & $\lambda_{\max }$ & $C V_{(\max , 5 \%)}$ & Prob.** \\
\hline$r=0$ & $r=1$ & 125.6943 & 22.29962 & $0.0000^{* *}$ \\
\hline$r \leq 1$ & $r=2$ & 10.01382 & 15.89210 & 0.3331 \\
\hline$r \leq 2$ & $r=3$ & 8.500166 & 9.164546 & 0.0667 \\
\hline
\end{tabular}

(a) $r$ is the number of cointegrating vectors.

(b) Trace test indicates 1 cointegrating equations at the $5 \%$ level of significance.

(c) Max-Eigen value test indicates 1 cointegrating equation at the 5\% level of significance.

(d)** denotes rejection of the null hypothesis at $5 \%$ level of significance.

(e) The critical values (i.e., CVs) are taken from Mackinnon-Haug-Michelis (1999).

Johansen's test reveals that the variables under study stand in a long run relationship among them, justifying the use of ECM for showing short run dynamics. In the Table 4 below, the cointegrating equations are given along with the equation for changes in GRWSER ((first column), changes in SOFTWARE (second column), changes in NONSOFTWARE (third column). The coefficients of ECT contain information about whether the past values affect the current values of the variable under study. A significant coefficient implies that past equilibrium errors play a role in determining the current outcomes. The short-run dynamics are captured through the individual coefficients of the difference terms.

The adjustment coefficient on $E C T_{t-1}$ in equation 3(a) is negative and statistically significant (at $1 \%$ level), which means that the error term contributes in explaining changes in GRWSER and a long-term relationship exists between the independent variables and GRWSER. In equation 
3(a) the estimates of lagged coefficients $\triangle L n S O F T W A R E_{t-3}$ is negative and statistically significant (at 1\% level), implying that higher software services export has a negative impact on GRWSER in the short-run. The estimates of lagged coefficients $\triangle L n N O N S O F T W A R E_{t-2}$ in equation 3(a) is negative and statistically significant at 5\% level implying that a higher non-software services export has a negative effect on GRWSER in the short-run.

The adjustment coefficient on $E C T_{t-2}$ in equation 3(b) is negative and statistically significant (at 1\% level), which means that the error term contributes in explaining changes in SOFTWARE and a long-term relationship exists between the independent variables and SOFTWARE.

The estimates of lagged coefficients $\triangle L n G R W S E R_{t-2}, \Delta L n G R W S E R_{t-3}$ in equation 3(b) are negative and statistically significant at 5\% level implying that a higher GRWSER has a negative on software exports in the short-run.

The adjustment coefficient on $E C T_{t-3}$ in equation 3(c) is negative and statistically significant (at 5\% level), which means that the error term contributes in explaining changes in NONSOFTWARE and a long-term relationship exists between the independent variables and NONSOFTWARE. The estimates of lagged coefficients $\triangle L n G R W S E R_{t-1}$ in equation 3(c) is negative and statistically significant at $5 \%$ level implying that a higher GRWSER has a negative impact on NONSOFTWARE in the short-run. The estimates of lagged coefficients

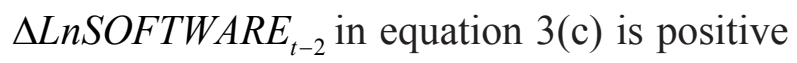
and statistically significant at $10 \%$ level implying that a higher SOFTWARE has a positive impact on NONSOFTWARE in the short-run.

Bidirectional causality is observed between software services export and growth of the services sector. Bidirectional causality is observed between non-software services export and growth of the services sector. Unidirectional causality is observed from software services export to non-software services export.

\section{Table 4: Vector Error Correction Estimates}

\begin{tabular}{|c|c|l|l|}
\hline \multicolumn{4}{|l|}{ Included observations: 32 after adjustments } \\
\hline Standard errors in ( ) \& t-statistics in [ ] & \\
\hline Cointegrating Eq: & CointEq1 & & \\
\hline LnGRWSER(-1) & 1.000000 & & \\
\hline & & & \\
\hline LnSOFTWARE(-1) & 0.194595 & & \\
\hline & $(0.27219)$ & & \\
\hline & {$[0.71493]$} & & \\
\hline & & & \\
\hline
\end{tabular}


On the Nexus between Services Export and Service Sector Growth in Indian Context

\begin{tabular}{|c|c|c|c|}
\hline LnNONSOFTWARE(-1) & -0.030509 & & \\
\hline & $(0.24699)$ & & \\
\hline & {$[-0.12352]$} & & \\
\hline $\mathrm{C}$ & -12.05835 & & \\
\hline & $(0.63773)$ & & \\
\hline & {$[-18.9084]$} & & \\
\hline Error Correction: & $\begin{array}{l}\text { D(LnGRWS- } \\
\text { ER) }\end{array}$ & $\begin{array}{l}\text { D(LnSOFT- } \\
\text { WARE) }\end{array}$ & $\begin{array}{c}\text { D(LnNONSOFT- } \\
\text { WARE) }\end{array}$ \\
\hline CointEq1 & -0.038998 & -0.067423 & -0.057300 \\
\hline & $(0.00120)$ & $(0.01239)$ & $(0.02679)$ \\
\hline & {$[-32.6205]^{* * *}$} & {$[-5.44342]^{* * *}$} & {$[-2.13881]^{* *}$} \\
\hline D(LnGRWSER(-1)) & -0.990185 & -0.766095 & -2.735546 \\
\hline & $(0.04919)$ & $(0.50963)$ & $(1.10230)$ \\
\hline & {$[-20.1300]$} & {$[-1.50323]$} & {$[-2.48167]^{* *}$} \\
\hline D(LnGRWSER(-2)) & -0.776081 & -1.342829 & -1.833709 \\
\hline & $(0.05785)$ & $(0.59938)$ & $(1.29643)$ \\
\hline & {$[-13.4148]$} & {$[-2.24035]^{* *}$} & {$[-1.41443]$} \\
\hline D(LnGRWSER(-3)) & -0.785609 & -1.131697 & 0.209605 \\
\hline & $(0.04928)$ & $(0.51056)$ & $(1.10431)$ \\
\hline & {$[-15.9421]$} & {$[-2.21659]^{* *}$} & {$[0.18981]$} \\
\hline D(LnSOFTWARE(-1)) & 0.017358 & -0.268675 & -0.029981 \\
\hline & $(0.01987)$ & $(0.20584)$ & $(0.44521)$ \\
\hline & {$[0.87370]$} & {$[-1.30529]$} & {$[-0.06734]$} \\
\hline D(LnSOFTWARE(-2)) & -0.030731 & -0.083573 & 0.899627 \\
\hline & $(0.02058)$ & $(0.21322)$ & $(0.46118)$ \\
\hline & {$[-1.49325]$} & {$[-0.39196]$} & {$[1.95072]^{*}$} \\
\hline D(LnSOFTWARE(-3)) & -0.075521 & -0.317722 & -0.432213 \\
\hline & $(0.02292)$ & $(0.23744)$ & $(0.51357)$ \\
\hline & {$[-3.29530]^{* * *}$} & {$[-1.33811]$} & {$[-0.84158]$} \\
\hline $\begin{array}{c}\text { D(LnNONSOFT- } \\
\text { WARE(-1)) }\end{array}$ & 0.016514 & 0.064235 & 0.224494 \\
\hline & $(0.00914)$ & $(0.09473)$ & $(0.20489)$ \\
\hline & [ 1.80612$]$ & {$[0.67810]$} & [ 1.09568$]$ \\
\hline
\end{tabular}




\begin{tabular}{|c|c|c|c|}
\hline $\begin{array}{c}\text { D(LnNONSOFT- } \\
\text { WARE(-2)) }\end{array}$ & -0.019741 & -0.089832 & -0.134978 \\
\hline & $(0.00806)$ & $(0.08351)$ & $(0.18063)$ \\
\hline & {$[-2.44909]^{* *}$} & {$[-1.07567]$} & {$[-0.74725]$} \\
\hline $\begin{array}{c}\text { D(LnNONSOFT- } \\
\text { WARE(-3)) }\end{array}$ & -0.019565 & 0.090075 & -0.170325 \\
\hline & $(0.00785)$ & $(0.08135)$ & $(0.17595)$ \\
\hline & {$[-2.49178]$} & {$[1.10728]$} & {$[-0.96802]$} \\
\hline R-squared & 0.982148 & 0.516804 & 0.399927 \\
\hline Adj. R-squared & 0.974844 & 0.319132 & 0.154443 \\
\hline F-statistic & 134.4816 & 2.614461 & 1.629135 \\
\hline
\end{tabular}

Impulse Response Analysis: The shock to IR function for the VAR system is calculated any one of the three variables considered in the in the following order - DLnGRWSER, study affects all other variables in the system. The shocks are orthogonalized by using the Choleski decomposition method.

DLnSOFTWARE, DLnNONSOFTWARE. The VAR is estimated at the first difference of the variables and the optimal lag length is chosen to be 3 .
Response of DNONSOFTWARE to DNONSOFTWARE

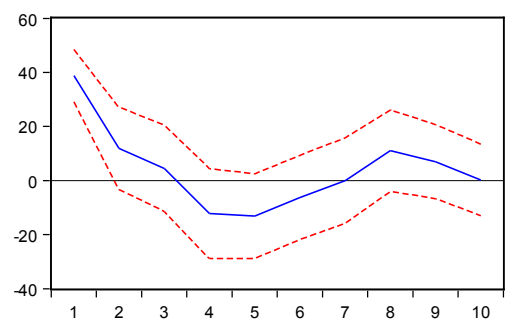

Response of DGRWSER to DNONSOFTWARE

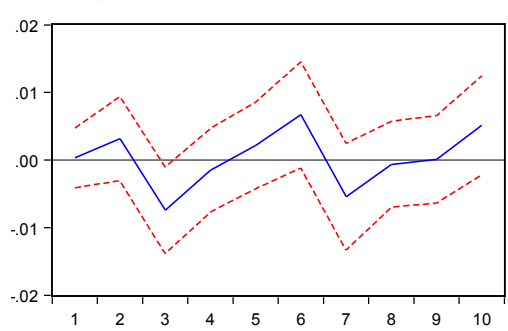

Response of DSOFTWARE to DNONSOFTWARE

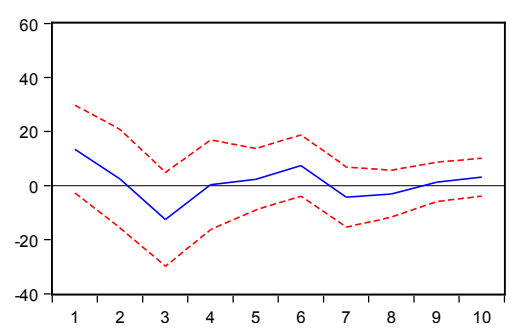

Response to Cholesky One S.D. Innovations \pm 2 S.E.

Response of DNONSOFTWARE to DGRWSER
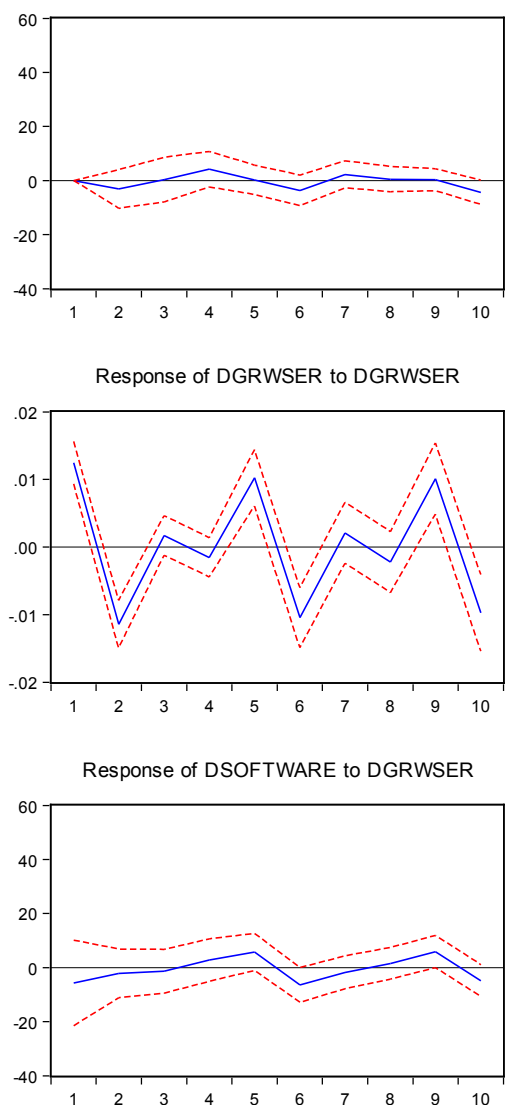

Response of DNONSOFTWARE to DSOFTWARE

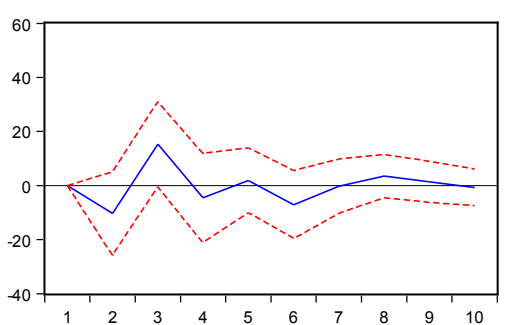

Response of DGRWSER to DSOFTWARE

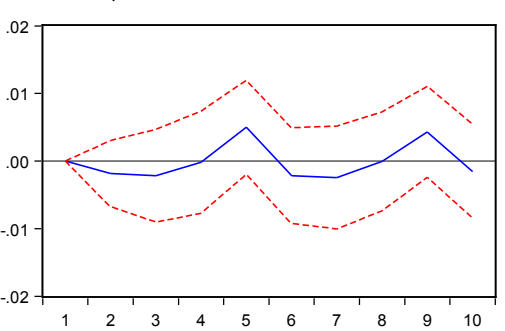

Response of DSOFTWARE to DSOFTWARE

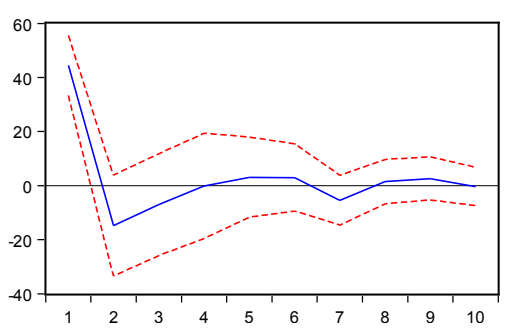

The Figure : Impulse Response Analysis 
The response of GRWSER to a unit shock in SOFTWARE is negative in the first three quarters. The response of GRWSER to a unit shock in NONSOFTWARE is positive in the first two quarters and starts falling in the third quarter. The response of SOFTWARE to unit shock in GRWSER is negative in the first three quarters. The response of NONSOFTWARE to a unit shock in GRESER is negative in the first three quarters.

\section{Conclusion}

The study reveals that both software services export and nonsoftware miscellaneous services export (business, financial and communication services) contributed to the growth of the services sector during the period of the study.

India continues to maintain a leadership position in global outsourcing, accounting for above 55 percent of the global sourcing market (excluding engineering services and $R \& D$ ) in 2013 compared to 52 percent in 2012. The ITbusiness process management (BPM) sector excluding hardware is estimated to have grown by 10.3 percent reaching US $\$ 105$ billion in 2013 14.A gradual revival in consumer confidence leading to return of discretionary spending and increased demand from the US and Europe is helping drive exports. India continues to lead in cost competitiveness. Flat entry-level salaries, flattening employee pyramid, and fast career growth are helping India stay seven-eight times cheaper than source locations and the next nearest low-cost country. Keeping pace with the global export of financial services, the country's financial services registered a high growth of 34.4 percent in 2013-14. The major business services including computer related services, research and development (R\&D), accounting services, legal services and renting of machinery etc had a share of 5.6 percent in India's GDP, but it grew by 14.1 percent in 2012-13.

However, challenges around protectionism, increased competition, currency volatility, wage inflation, and inconsistent levels of customer confidence have to be addressed. Proper reforms along with speeding up of the policy decision making could lead to consistent services sector growth for India. The resilience of services growth witnessed even during and in the aftermath of the 2008 global recession has started waning, though services sector growth is still higher than that of other sectors. While the slowdown in the manufacturing and mining sectors directly affected some services like railways, shipping, ports, and other related services on account of the strong linkage effect, other services were affected by the income effect with slowdown in growth of both global and domestic incomes. Some quick reforms and removal of barriers and obsolete regulations could further help this revival. Software and telecom services help the country in giving a brand image. Export of services still remain constrained by domestic and external barriers (technical, standard financial and infrastructure) and regulatory aspects.

In case of India, certain services- financial and business including IT services, legal, engineering, communication services, domestic regulations of specific nature imposed by the US denies market access for these services. Europe and UK also deny market access via regulations (entertainment services, travel and tourism). 
Finally apart from domestic regulations imposed by countries, huge subsidies levied on domestic goods also act as a regulatory barrier on market access. Liberalizing and regulating the policy environment could lead to developing a more efficient services sector in India. Many services provide crucial inputs for manufacturing industries so efficient service sector would arrest the manufacturing slide in India and lead to competitive manufacturing environment. Moreover quality services would also enhance FDI flows.

The services sector growth is crucial for any country so as for India also. Services, the largest sector in the world accounts for more than $70 \%$ of the global output. The service revolution have altered the characteristics of services and provides alternative opportunities to find niches, beyond manufacturing, where the developing countries can specialize, scale up and achieve explosive growth, just like the industrialisers. A developing countries like India can sustain service led growth as there is a huge room for catch up and convergence.

\section{References}

Banga, R. \& Goldar, B.N., 2007. Contribution of services to output growth productivity in Indian manufacturing: pre and post reforms. Economic and Political Weekly, 42(26): 2769-2777.

Dickey, D.A. \& Fuller, W.A., 1979. Distribution of the estimations for autoregressive time series with a unit root. Journal of American Statistical Association, 74(366): 427-431.
Engle, R. F. \& Granger, C. W. J., 1987. Cointegration and Error-Correction: Representation, Estimation, and Testing, Econometrica, 55(2): 251-276.

Francois, J. \& Reinert, K., 1996. The Role of Services in the Structure of Production and Trade: Stylized Facts from a CrossCountry Analysis, Asia-Pacific Economic Review, 2(1): 35-43.

Francois, J., 1990. Producer Services, Scale and the Division of Labor, Oxford Economic Papers, 42(4): 715-729.

Goldsmith, R., 1969. Financial Structure and Development. New Haven and London: Yale University Press.

Johansen, S., 1988. Statistical Analysis of Cointegrating Vectors, Journal of Economic Dynamics and Control. 12(6): 231-254.

Johansen, S. \& Juselius, K., 1990. Maximum Likelihood Estimation and Inference on Co-integration with Application to the Demand for Money, Oxford Bulletin of Economics and Statistics, 52(2): 169-210.

King, R. \& Levine, R., 1993. Finance and Growth: Schumpter Might be Right, Quarterly Journal of Economics, 108(3): pp. 717-737. 